\title{
Can contrasting environmental conditions of mangroves induce morphological variability in Aratus pisonii (Crustacea: Brachyura: Sesarmidae)?
}

\author{
Beatriz López-Sánchez, Enrique Quintero-Torres, Adriana Oliveiras-Durand \\ Laboratorio de Ecología y Genética de Poblaciones, Centro de Ecología, Instituto Venezolano de Investigaciones Científi- \\ cas, Apartado Postal 20632, 1020-A Caracas, Venezuela. E-mail: blopez@ivic.gob.ve
}

\begin{abstract}
Summary: Aratus pisonii is one of the most common crab species in Neotropical mangroves. It shows great plasticity in its life history traits, which makes it an interesting subject for comparative studies. This study evaluated the morphometric variability in five populations of A. pisonii inhabiting mangroves with different degrees of structural development under contrasting environmental conditions. Mangrove forests located on the northwest coast of Venezuela were studied during the rainy season in 2006. The results showed morphometric differences and interaction between sampling sites and sex (PERMANOVA, $\mathrm{P}=0.0001$ ), as well as the presence of five morphological groups in males and four in females. The findings support the existence of sexual dimorphism. Females from the dwarf hypersaline mangrove showed a wide variability associated with the chelipeds. The differences in crab morphology between sites seem to be related to a combination of environmental factors that is unique for each habitat, leading to the formation of different morphological groups, in which the mangrove structural development (resource availability) and salinity (which compromises the energy budget) play an important role. The presence of more robust chelipeds in females from the dwarf hypersaline mangrove seems to reflect an adaptation to the biomechanical properties of the leaves (sclerophylly).
\end{abstract}

Keywords: mangrove crab; classic morphometry; sexual dimorphism; multivariate methods; chelipeds.

¿Las condiciones ambientales contrastantes de manglares pueden promover variabilidad morfológica en Aratus pisonii (Crustacea: Brachyura: Sesarmidae)?

Resumen: Aratus pisonii es una de las especies de cangrejos más comunes en manglares neotropicales, mostrando una gran plasticidad en las características de su historia de vida, lo cual hace a este organismo interesante para estudios comparativos. Esta investigación evaluó la variabilidad morfométrica en cinco poblaciones de A. pisonii que habitan manglares con diferentes grados de desarrollo estructural bajo condiciones ambientales contrastantes. Se estudiaron los bosques de manglar localizados en la costa noroeste de Venezuela durante la estación lluviosa en 2006. Los resultados indicaron diferencias morfométricas e interacción entre sitios de muestreo y sexos (PERMANOVA, $\mathrm{P}=0.0001$ ), así como la presencia de cinco grupos morfológicos en machos y cuatro en hembras. Los hallazgos soportan la existencia de dimorfismo sexual. Hembras del manglar achaparrado hipersalino mostraron una amplia variabilidad asociada con los quelípedos. Las diferencias en la morfología de los cangrejos entre sitios parecen responder a una combinación de factores ambientales únicos de cada hábitat, conllevando a la formación de diferentes grupos morfológicos, donde el desarrollo estructural del manglar (el cual representa la disponibilidad de recursos) y la salinidad (la cual compromete el presupuesto energético) juegan un papel importante. La presencia de quelípedos más robustos en hembras del manglar achaparrado hipersalino parece reflejar una adaptación a las propiedades biomecánicas de las hojas (esclerofilia).

Palabras clave: cangrejo de manglar; morfometría clásica; dimorfismo sexual; métodos multivariados; quelípedos.

Citation/Como citar este artículo: López-Sánchez B., Quintero-Torres E., Oliveiras-Durand A. 2016. Can contrasting environmental conditions of mangroves induce morphological variability in Aratus pisonii (Crustacea: Brachyura: Sesarmidae)? Sci. Mar. 80(3): 349-358. doi: http://dx.doi.org/10.3989/scimar.04427.27A

Editor: E. Macpherson.

Received: February 22, 2016. Accepted: May 20, 2016. Published: September 27, 2016.

Copyright: (C) 2016 CSIC. This is an open-access article distributed under the terms of the Creative Commons Attribution (CC-by) Spain 3.0 License. 


\section{INTRODUCTION}

The sesarmid crab Aratus pisonii (H. Milne Edwards, 1837) is one of the most common species in Neotropical mangroves (Hartnoll 1965). It is a treeliving crab and its diet is based mainly on mangrove leaves, although it can occasionally use other resources present in the environment (algae, insects, molluscs, nematodes, foraminifera and sea-grasses) (Díaz and Conde 1988, Erickson et al. 2003, López and Conde 2013). This species lives in a wide variety of habitats, including river mouths and estuarine, marine and hypersaline environments, where it can be found associated with several species of mangroves, such as Rhizophora mangle, Avicennia germinans, A. schaueriana, Laguncularia racemosa and Pelliceria rhizophorae (Conde 1990, Feller and Chamberlain 2007).

Conde and Díaz (1992) found that the relative size at onset of maturity (RSOM) of Aratus pisonii differs significantly between ecologically dissimilar locations along the Venezuelan coast, though this parameter has been considered as a constant characteristic within the crustacean group (Charnov 1990). Individuals of populations living in shrub and dwarf mangroves located in hypersaline lagoons are reduced in size and differ significantly from individuals of populations found in arboreal mangroves, especially those located in estuaries and river mouths, where ovigerous females have been found with sizes three times larger than those living in arbustive or dwarf mangroves (Conde and Díaz 1989a, b, Conde 1990). These results have shown a great plasticity in some features of $A$. pisonii's life history. However, these studies only took into account the carapace width, and it is unknown how other morphological measurements, such as those related to chelipeds, abdomen and body height, respond to variations in habitat conditions.

Conde and Díaz (1989a) suggest a conceptual model in order to explain this broad phenotypic plasticity that is mainly observed in the size of the crab, proposing that it may be due to a response to the particular conditions of the habitat, particularly the productivity of the mangroves (Conde and Díaz 1989a, Conde et al. 1989, 2000). Other studies have confirmed the broad plasticity of this species, associating it with the structural development of mangroves (Negreiros-Fransozo 2002). Recent studies confirm that the variety of resources consumed by $A$. pisonii is closely related to the structural development of the mangroves where they live (López and Conde 2013). Moreover, it has been found that the reproductive performance of this species responds to a gradient of structural complexity of the mangroves, and that fertility and the weight of the egg mass are correlated equally with the size of the crab, as well as with the environmental variables (salinity and structural development of the mangrove) (LópezSánchez and Quintero-Torres 2015).

The use of multivariate methods is recommended for the analysis of morphological features, because every organism is essentially multi-dimensional. Morphometric studies based on multivariate tests have been carried out in decapod crustaceans for a variety of purposes, e.g. to study growth patterns and to determine sexual maturity (Grandjean et al. 1997, Muiño et al. 1999, Sampedro et al. 1999, Fernandez-Vergaz et al. 2000), as well as to study interpopulation (GarcíaDávila et al. 2005) and intrapopulation variations in the same habitat (Maynou and Sardà 1997, Bas and Sardà 1998) or between habitats (Anastasiadou and Leonardos 2008, Contreras et al. 2013, Deli et al. 2014). Body shape is the main phenotypical component in an organism, and may affect other traits, such as feeding efficiency, locomotion, predation susceptibility and reproductive success (Guill et al. 2003). These features are partially determined by genes and strongly influenced by environmental conditions (Cabral et al. 2003). A change in the species phenotype caused by environmental conditions (phenotypic plasticity) can provide better tolerance conditions for this species (Via et al. 1995). Therefore, variation in body shape may be due to the influence of environmental factors, which is interpreted as an important adaptive strategy to changing or stressful environmental patterns (Trussell and Smith 2000).

Given the proven high plasticity of Aratus pisonii in its life history features, this study aims to assess the potential morphological variation in populations of the crab inhabiting mangroves with varying degrees of structural development located in different environments (estuarine, marine and hypersaline), by using traditional morphometric analysis and multivariate methods.

\section{MATERIALS AND METHODS}

\section{Study area}

Five mangrove forests with different grades of structural development were studied on the northwest coast of Venezuela (Falcón State). Four of these mangroves are located in Paraguaná Peninsula and one mangrove is on the continent, on the Ricoa River mouth (Fig. 1). These mangroves make up a gradient of structural complexity characterized by a progressive decrease in their basal area and trunk height that corresponds to salinity changes: from estuarine arboreal (EA-BR), marine arboreal (MA-TIM), hypersaline arboreal (HA-TIB), hypersaline arbustive (HArTIA) to hypersaline dwarf mangroves (HD-TAC) (López 2010, López et al. 2011). The predominant mangrove species in this system is Rhizophora mangle, with the exception of the estuarine mangrove, which is dominated by the white mangrove Laguncularia racemosa (L.). The River Ricoa shows two annual rainfall pulses (Fig. 1), while in Paraguaná Peninsula, where rainfall is the only source of freshwater for the mangroves, there is only a short rainy period that usually last from October to November, in a predominantly dry climate with a long period of drought (Conde 1990); the rainfall is the only source of freshwater for the mangroves of the Paraguaná Peninsula. For more details about this study area, see López et al. (2011) and López-Sánchez and Quintero-Torres (2015). 

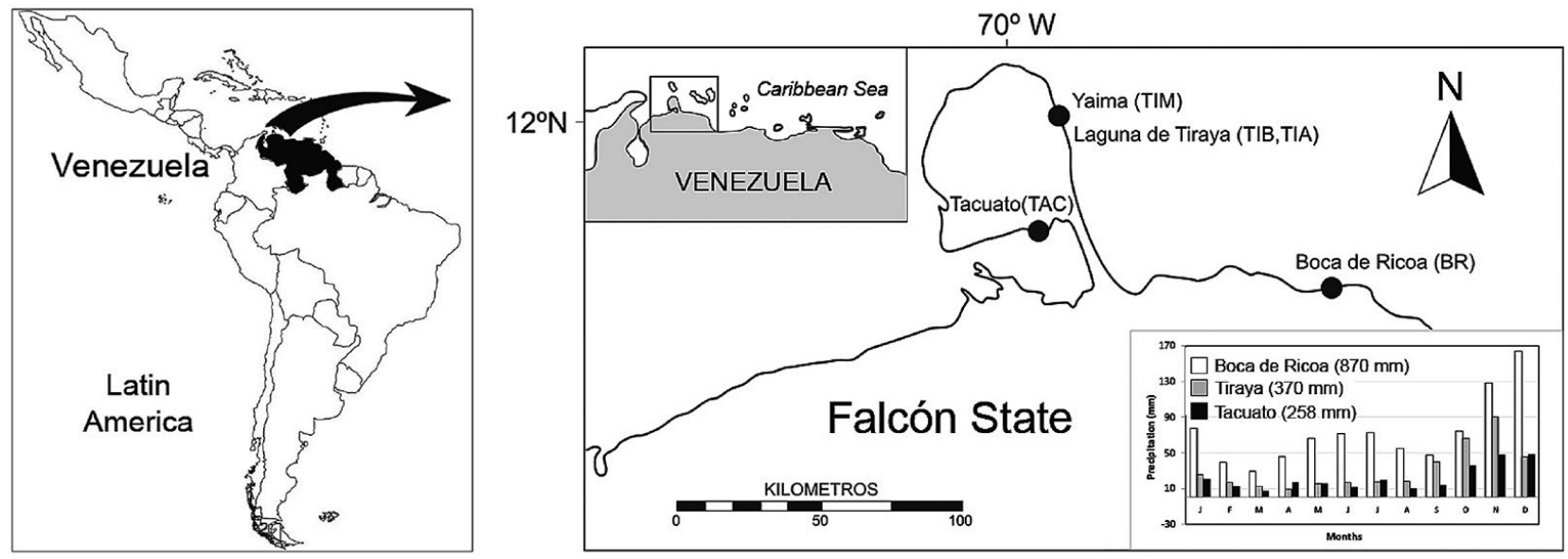

Fig. 1. - Geographic localization of Venezuela. Relative location of Falcón State (Venezuela). Black solid dots show the sampling sites for Aratus pisonii. Yaima (TIM: $12^{\circ} 03^{\prime} 10^{\prime \prime} \mathrm{N}-69^{\circ} 51^{\prime} 09^{\prime \prime} \mathrm{W}$ ), Laguna de Tiraya (TIB: $12^{\circ} 01^{\prime} 53^{\prime \prime} \mathrm{N}-69^{\circ} 51^{\prime} 15^{\prime \prime} \mathrm{W}$; TIA: $12^{\circ} 02^{\prime} 05^{\prime \prime} \mathrm{N}-9^{\circ} 50^{\prime} 48^{\prime \prime} \mathrm{W}$ ) and Tacuato (TAC: $11^{\circ} 41^{\prime} 21^{\prime \prime} \mathrm{N}-69^{\circ} 49^{\prime} 58^{\prime \prime} \mathrm{W}$ ) are located on the Paraguaná Peninsula (Falcón State); Boca de Ricoa (BR: $11^{\circ} 30^{\prime} 11^{\prime \prime} \mathrm{N}$ $69^{\circ} 12^{\prime} 27^{\prime \prime} \mathrm{W}$ ) on the continent. Inset: Monthly and annual mean precipitation (MINAMB 2004).

\section{Sampling}

Adult crabs (which could be sexed by the naked eye) were hand-collected from September to November (rainy season) 2006 at the five sampling sites mentioned above. Captured crabs were enclosed immediately in individual labelled plastic bags, and frozen to be further transported to the laboratory. Only specimens with complete chelipeds and without signs of autotomy were considered for analysis.

\section{Morphometric measurements of Aratus pisonii}

Each specimen was measured using a vernier caliper. Ten body measurements were considered (Fig. 2): carapace length (CL), height of body (HB), maximum and minimum carapace width (CW1, CW2 respectively), abdomen width (AW), abdomen length (AL), right length cheliped (RLCh), right height cheliped (RHCh), left length cheliped (LLCh) and left height cheliped (LHCh).

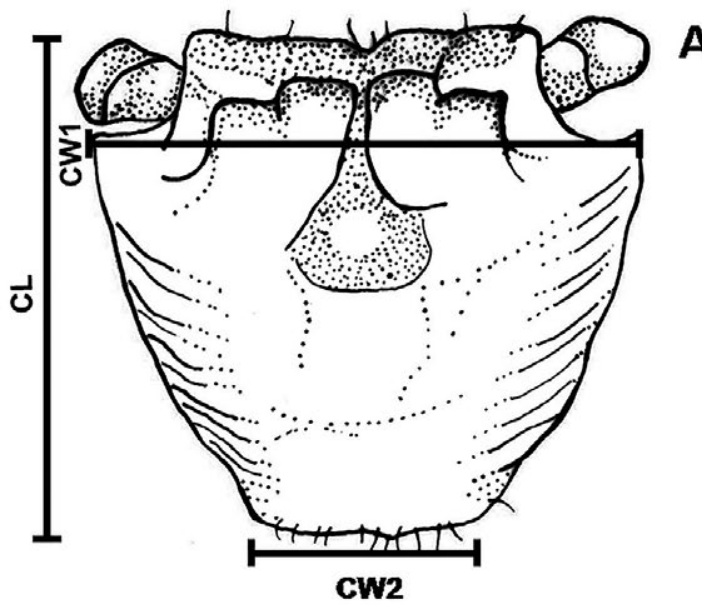

$A$
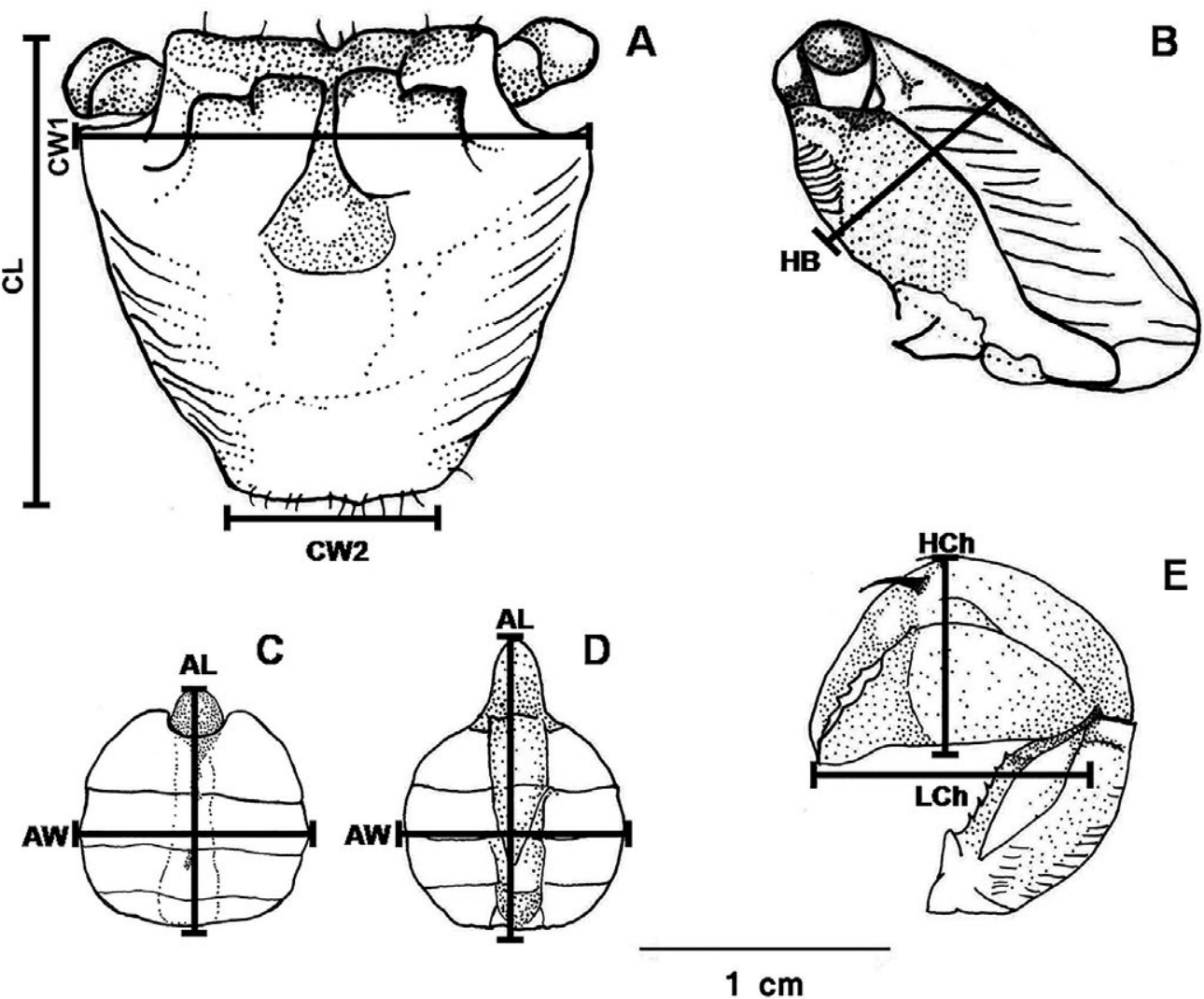

E

Fig. 2. - Illustration of morphological dimensions measured in Aratus pisonii. A, dorsal view of the carapace (CL, carapace length; CW1, CW2, maximum and minimum carapace width); B, height of body (HB); C, female abdomen; D, male abdomen (AL, abdomen length; AW, abdomen width); E, lateral view of left cheliped, length cheliped (LCh) and height cheliped (HCh). 
Table 1. - Mean values $( \pm \mathrm{se})$ of morphometric variables $(\mathrm{mm})$ of males $(\hat{\jmath})$ and females $(q \circ)$ of $A$. pisonii. Abbreviations: EA-BR, estuarine arboreal mangrove of Boca de Ricoa; MA-TIM, marine arboreal mangrove of Tiraya Marina; HA-TIB, hypersaline arboreal mangrove of Tiraya B; HAr-TIA, hypersaline arbustive mangrove of Tiraya A; and HD-TAC, hypersaline dwarf mangrove of Tacuato. Different letters indicate groups with significant differences between sites according to pairwise comparison $(\mathrm{PERMANOVA,}<0.05)$. ns $=$ not significant, * $\mathrm{P}<0.05, * * \mathrm{P}<0.01$ and $* * * \mathrm{P}<0.001$. This analysis was performed with the standardized data (except CW1).

\begin{tabular}{|c|c|c|c|c|c|c|}
\hline Variable & Sex & $\begin{array}{c}\text { EA-BR } \\
51 \delta \hat{\alpha}, 56 \text { 우 }\end{array}$ & $\begin{array}{c}\text { MA-TIM } \\
39 \hat{\jmath} \bar{\alpha}, 579+9\end{array}$ & $\begin{array}{c}\text { HA-TIB } \\
54 \hat{\jmath}, 55 \text { o }\end{array}$ & $\begin{array}{c}\text { HAr-TIA } \\
59 \hat{\jmath}, 50 \text { o } 9 \text { + }\end{array}$ & $\begin{array}{c}\text { HD-TAC } \\
54 \hat{\jmath}, 40 \text {. }\end{array}$ \\
\hline CW1 & $\begin{array}{l}1 \\
0 \\
0 \\
+ \\
\end{array}$ & $\begin{array}{c}20.96 \pm 0.45^{\mathrm{a}} \\
20.38 \pm 0.37^{\mathrm{a}} \\
\hat{\lambda}=\varnothing \mathrm{ns}\end{array}$ & $\begin{array}{c}19.51 \pm 0.47^{\mathrm{b}} \\
19.56 \pm 0.27^{\mathrm{a}} \\
\hat{d}=\text { Ons }\end{array}$ & $\begin{array}{c}20.40 \pm 0.50^{\mathrm{ab}} \\
18.11 \pm 0.28^{\mathrm{b}} \\
\gamma^{>}>0 * * *\end{array}$ & $\begin{array}{c}17.90 \pm 0.41^{\mathrm{c}} \\
15.90 \pm 0.32^{\mathrm{c}} \\
\hat{j}>0 * * *\end{array}$ & $\begin{array}{c}15.02 \pm 0.28^{\mathrm{d}} \\
15.70 \pm 0.30^{\mathrm{c}} \\
\hat{\delta}=\text { Ons }\end{array}$ \\
\hline $\mathrm{CL}$ & $\begin{array}{l}0 \\
0 \\
+\end{array}$ & $\begin{array}{c}20.05 \pm 0.05^{\mathrm{a}} \\
20.06 \pm 0.04^{\mathrm{a}} \\
\hat{\delta}=\emptyset \mathrm{ns}\end{array}$ & $\begin{array}{c}18.48 \pm 0.08^{\mathrm{b}} \\
19.04 \pm 0.05^{\mathrm{b}} \\
\hat{j}<0 * * *\end{array}$ & $\begin{array}{c}18.61 \pm 0.09^{\mathrm{b}} \\
17.11 \pm 0.04^{\mathrm{c}} \\
\dot{\lambda}>0 * * *\end{array}$ & $\begin{array}{c}16.56 \pm 0.10^{\mathrm{c}} \\
14.97 \pm 0.08^{\mathrm{d}} \\
\bar{\lambda}>0 * * *\end{array}$ & $\begin{array}{c}14.70 \pm 0.02^{\mathrm{d}} \\
14.69 \pm 0.04^{\mathrm{e}} \\
\hat{\delta}=\text { Ons }\end{array}$ \\
\hline CW2 & $\begin{array}{l}0 \\
0 \\
+\end{array}$ & $\begin{array}{c}5.49 \pm 0.04^{\mathrm{a}} \\
5.92 \pm 0.03^{\mathrm{a}} \\
\delta^{2}<q * * *\end{array}$ & 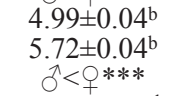 & $\begin{array}{c}4.75 \pm 0.04^{\mathrm{c}} \\
5.01 \pm 0.04^{\mathrm{c}} \\
\delta^{2}<0 * * *\end{array}$ & $\begin{array}{c}4.48 \pm 0.07^{\mathrm{d}} \\
4.47 \pm 0.05^{\mathrm{d}} \\
\hat{\delta}=q \mathrm{~ns}\end{array}$ & $\begin{array}{c}4.15 \pm 0.02^{\mathrm{e}} \\
4.27 \pm 0.05^{\mathrm{e}} \\
\lambda<{ }^{*}\end{array}$ \\
\hline AW & $\begin{array}{l}\hat{0} \\
\text { q }\end{array}$ & $\begin{array}{c}10.24 \pm 0.10^{\mathrm{a}} \\
12.20 \pm 0.13^{\mathrm{a}} \\
\hat{\delta}<q_{+} * *\end{array}$ & $\begin{array}{c}9.43 \pm 0.05^{\mathrm{b}} \\
11.88 \pm 0.05^{\mathrm{b}} \\
\hat{j}<q^{\circ} * *\end{array}$ & $\begin{array}{c}9.60 \pm 0.07^{\mathrm{c}} \\
10.62 \pm 0.04^{\mathrm{c}} \\
\hat{\delta}<{ }^{\mathrm{c}} * * *\end{array}$ & $\begin{array}{c}8.11 \pm 0.05^{\mathrm{d}} \\
9.17 \pm 0.07^{\mathrm{d}} \\
\delta<0 * * *\end{array}$ & $\begin{array}{c}7.48 \pm 0.07^{\mathrm{e}} \\
8.26 \pm 0.15^{\mathrm{e}} \\
\delta<0 * * *\end{array}$ \\
\hline $\mathrm{AL}$ & $\begin{array}{l}0 \\
0 \\
+\end{array}$ & $\begin{array}{c}14.12 \pm 0.06^{\mathrm{a}} \\
14.62 \pm 0.06^{\mathrm{a}} \\
\hat{j}<0 * * *\end{array}$ & $\begin{array}{c}12.59 \pm 0.06^{\mathrm{b}} \\
13.73 \pm 0.07^{\mathrm{b}} \\
\overline{3}<0^{\circ} * *\end{array}$ & $\begin{array}{c}13.31 \pm 0.14^{\mathrm{c}} \\
12.53 \pm 0.05^{\mathrm{c}} \\
\hat{j}>0 * * *\end{array}$ & $\begin{array}{c}11.30 \pm 0.05^{\mathrm{d}} \\
10.89 \pm 0.09^{\mathrm{d}} \\
\hat{\delta}>0 * * *\end{array}$ & $\begin{array}{c}10.14 \pm 0.04^{\mathrm{e}} \\
10.25 \pm 0.08^{\mathrm{e}} \\
\hat{\delta}=\mathrm{Q}^{\mathrm{ns}}\end{array}$ \\
\hline HB & $\begin{array}{l}\hat{0} \\
0 \\
+\end{array}$ & $\begin{array}{c}9.14 \pm 0.05^{\mathrm{a}} \\
8.79 \pm 0.04^{\mathrm{a}} \\
3>0 * * *\end{array}$ & $\begin{array}{c}8.28 \pm 0.06^{\mathrm{b}} \\
8.58 \pm 0.05^{\mathrm{b}} \\
\hat{1}<0^{\circ} * *\end{array}$ & $\begin{array}{c}8.93 \pm 0.05^{\mathrm{c}} \\
7.57 \pm 0.04^{\mathrm{c}} \\
\grave{3}>0 * * *\end{array}$ & $\begin{array}{c}7.41 \pm 0.05^{\mathrm{d}} \\
6.43 \pm 0.07^{\mathrm{d}} \\
\delta>0 * * *\end{array}$ & $\begin{array}{c}6.52 \pm 0.05^{\mathrm{e}} \\
6.32 \pm 0.08^{\mathrm{d}} \\
\lambda>q^{*}\end{array}$ \\
\hline RLCh & $\begin{array}{l}\hat{\sigma} \\
0 \\
+\end{array}$ & $\begin{array}{c}11.11 \pm 0.12^{\mathrm{a}} \\
8.97 \pm 0.09^{\mathrm{a}} \\
\hat{1}>0 * * *\end{array}$ & $\begin{array}{c}10.22 \pm 0.09^{\mathrm{b}} \\
8.76 \pm 0.05^{\mathrm{b}} \\
\bar{\lambda}>0 * * *\end{array}$ & $\begin{array}{c}11.80 \pm 0.15^{\mathrm{c}} \\
7.72 \pm 0.04^{\mathrm{c}} \\
\dot{\lambda}>0 * * *\end{array}$ & $\begin{array}{c}9.58 \pm 0.07^{\mathrm{d}} \\
6.61 \pm 0.07^{\mathrm{d}} \\
\delta^{>}>0^{2} * *\end{array}$ & $\begin{array}{c}8.47 \pm 0.04^{\mathrm{e}} \\
7.37 \pm 0.16^{\mathrm{e}} \\
\hat{\lambda}>0 * * *\end{array}$ \\
\hline LLCh & $\begin{array}{l}\hat{0} \\
0 \\
+\end{array}$ & $\begin{array}{c}11.19 \pm 0.12^{\mathrm{a}} \\
9.06 \pm 0.09^{\mathrm{a}} \\
\bar{j}>0 * * *\end{array}$ & $\begin{array}{c}10.22 \pm 0.09^{\mathrm{b}} \\
8.70 \pm 0.04^{\mathrm{b}} \\
\lambda^{\prime}>0 * * *\end{array}$ & $\begin{array}{c}11.64 \pm 0.13^{\mathrm{c}} \\
7.71 \pm 0.05^{\mathrm{c}} \\
\delta^{\prime}>0 * *\end{array}$ & $\begin{array}{c}9.48 \pm 0.09^{d} \\
6.42 \pm 0.07^{d} \\
d>0 * * *\end{array}$ & $\begin{array}{c}8.51 \pm 0.04^{\mathrm{e}} \\
7.39 \pm 0.17^{\mathrm{e}} \\
\lambda>0 * * *\end{array}$ \\
\hline RHCh & $\begin{array}{l}1 \\
0\end{array}$ & $\begin{array}{c}6.49 \pm 0.10^{\mathrm{a}} \\
4.84 \pm 0.03^{\mathrm{a}} \\
\overline{1}>0 * * *\end{array}$ & $\begin{array}{c}5.78 \pm 0.07^{\mathrm{b}} \\
4.50 \pm 0.03^{\mathrm{b}} \\
3>0 * * *\end{array}$ & $\begin{array}{c}7.19 \pm 0.08^{\mathrm{c}} \\
4.04 \pm 0.04^{\mathrm{c}} \\
3>0 * * *\end{array}$ & $\begin{array}{c}5.76 \pm 0.06^{\mathrm{d}} \\
3.36 \pm 0.05^{\mathrm{d}} \\
\delta>0 * * *\end{array}$ & $\begin{array}{c}5.22 \pm 0.04^{\mathrm{d}} \\
4.15 \pm 0.14^{\mathrm{c}} \\
\hat{\lambda}>0 * * *\end{array}$ \\
\hline $\mathrm{LHCh}$ & $\begin{array}{l}\hat{0} \\
0 \\
+\end{array}$ & $\begin{array}{c}6.60 \pm 0.05^{\mathrm{a}} \\
4.82 \pm 0.03^{\mathrm{a}} \\
3>0 * * *\end{array}$ & $\begin{array}{c}5.82 \pm 0.07^{\mathrm{b}} \\
4.50 \pm 0.03^{\mathrm{b}} \\
\delta^{>}>* * *\end{array}$ & $\begin{array}{c}7.16 \pm 0.09^{\mathrm{c}} \\
4.04 \pm 0.04^{\mathrm{c}} \\
1>0 * * *\end{array}$ & $\begin{array}{c}5.68 \pm 0.08^{\mathrm{b}} \\
3.45 \pm 0.04^{\mathrm{d}} \\
3>0 * * *\end{array}$ & $\begin{array}{c}5.17 \pm 0.04^{\mathrm{d}} \\
4.21 \pm 0.14^{\mathrm{c}} \\
3>0 * * *\end{array}$ \\
\hline
\end{tabular}

\section{Statistical analysis}

The allometric equation $\mathrm{Y}=\mathrm{aX}{ }^{\mathrm{b}}$ was employed to remove the effect of crab size (CW1, X) on each measured variable (Y) (Tzeng 2004). For each of the five crab populations, allometric regressions were performed for the nine body dimensions (CL, HB, CW2, AW, AL, RLCh, RHCh, LLCh, LHCh) vs CW1. A consistent positive allometry between variables and CW1 arose in the different populations analysed for each sex. All variables were standardized through equation $\mathrm{Yi}^{*}=\mathrm{Yi}(\mathrm{Xm} / \mathrm{Xi})^{\mathrm{b}}$, where $\mathrm{Yi}^{*}$ is the morphometric standardized measure in the $\mathrm{i}^{\text {th }}$ specimen, $\mathrm{Yi}$ is the morphometric non-standardized measure in the $\mathrm{i}^{\text {th }}$ specimen, $\mathrm{Xi}$ is the measure of maximum carapace width in the $i^{\text {th }}$ specimen, $\mathrm{Xm}$ is the mean maximum carapace width for each sampling site and sex, and $b$ is the standardized parameter obtained from the allometric equation (Anastasiadou and Leonardos 2008, Deli et al. 2014).

The standardized morphometric measures were averaged ( \pm se) for each sampling site and sex. A twoway analysis of variance (sites and sex) based on permutations (PERMANOVA) - from Euclidean distance matrix - and a posteriori test of multiple comparisons (pairwise comparisons) was carried out to evaluate differences between all pair levels of each factor (Anderson 2001).

The CW1 variable was excluded from all multivariate analyses. A non-metric multi-dimensional scaling (nMDS) was employed, set with 250 restarts, to visualize patterns of dispersion in the multivariate ordina- tion of samples. Two-way multivariate PERMANOVA was conducted to test whether there were differences and significant multivariate interaction between factors (sites and sex). PERMDISP was run to test the homogeneity of the multivariate dispersion of data. Components of variation (sum of squares of the fixed effects divided by appropriate degrees of freedom) for each term in the model of PERMANOVA were estimated as a measure of the magnitude effect (Anderson et al. 2008).

In addition, a canonical analysis of principal coordinates (CAP) for each sex was conducted to maximize the differences in the multivariate space, and to search for the combination of variables that best separated the different groups (sites) set a priori; the significance of discrimination was obtained through the trace statistic (tr(Q_m'HQ_m)) (Anderson and Willis 2003, Anderson et al. 2008). Finally, degree of dissimilarity between discriminated crab populations from the CAP, and the contribution (\%) of each variable to the dissimilarity among sites was determined with a SIMPER. The P values of all analyses were obtained from 9999 permutations, using PRIMER 6.1.13 and PERMANOVA 1.0.3 software (Clarke and Gorley 2006, Anderson et al. 2008).

\section{RESULTS}

A total of 515 specimens, 257 males and 258 females, were collected and measured. CW1 of males ranged from $10.96 \mathrm{~mm}$ in $\mathrm{HD}$-TAC to $27.14 \mathrm{~mm}$ in EA-BR. For females it ranged from $11.31 \mathrm{~mm}$ in HD- 
Table 2. - Two-factor multivariate PERMANOVA and PERMDISP results based on Euclidean distance measures estimated since standardized morphometric variables of Aratus pisonii. $\sqrt{ }$ C.V.: Square root of estimates of components of variation.

\begin{tabular}{|c|c|c|c|c|c|c|c|}
\hline $\begin{array}{l}\text { PERMANOVA } \\
\text { Source }\end{array}$ & df & SS & MS & Pseudo-F & $P_{(\text {perm })}$ & $\begin{array}{c}\text { Unique } \\
\text { permutations }\end{array}$ & $\sqrt{ }$ C.V. $(\%)$ \\
\hline Site & 4 & 5469.10 & 1367.30 & 561.81 & 0.0001 & 9939 & $3.67(36)$ \\
\hline Sex & 1 & 2650.10 & 2650.10 & 1088.90 & 0.0001 & 9937 & $3.24(31)$ \\
\hline SitexSex & 4 & 682.98 & 170.75 & 70.16 & 0.0001 & 9934 & $1.82(18)$ \\
\hline Res & 505 & 1229.00 & 2.43 & & & & $1.56(15)$ \\
\hline Total & 514 & 10178.00 & & & & & \\
\hline \multicolumn{8}{|l|}{ PERMDISP } \\
\hline Source & df1 & df2 & & $\mathrm{F}$ & $\mathrm{P}_{(\text {perm })}$ & & \\
\hline$\overline{\text { Site }}$ & 4 & 510 & & 98.810 & 0.0001 & & \\
\hline Sex & 1 & 513 & & 0.031 & 0.8598 & & \\
\hline Site $\times$ sex & 9 & 505 & & 13.003 & 0.0001 & & \\
\hline
\end{tabular}

TAC to $28.74 \mathrm{~mm}$ in EA-BR. CW1 decreased towards hypersaline mangroves with less structural development, where significantly lower values of this variable were recorded (pairwise PERMANOVA, $\mathrm{P}<0.05$ ) (Table 1). Statistically significant interaction were found between sites and sex for each standardized morphometric measurement (PERMANOVA; $\mathrm{P}<0.001$ ). More specifically, the differences between males and females did not show a consistent pattern across sampling sites; males were larger than females (CL) at only two sampling sites (HA-TIB, HAr-TIA), while at the other sites there were no differences between sexes (EA-BR, HD-TAC) or females showed higher values (MA-TIM). Males showed a greater height and length of both chelipeds (right and left) than females at all sites (Table 1).

Multivariate PERMANOVA results showed a significant interaction between sites and sex (PERMANOVA, pseudo- $\left.\mathrm{F}_{4,505}=70.16, \mathrm{P}=0.0001\right)$. The sampling site made the greatest contribution to components of variation (36\%) f ollowed by sex (31\%) (Table 2), clearly showing the existence of sexual dimorphism in Aratus pisonii. This finding supports the suggestion that female and male crabs should be considered independently for further analyses. On the other hand, PERMDISP analyses indicated that the multivariate dispersion of samples was significant for the sampling site and the interaction (PERMDISP, $\mathrm{F}_{9,505}=13$, $\mathrm{P}=0.0001$ ) (Table 2). Therefore, PERMANOVA results should be treated with caution since this analysis

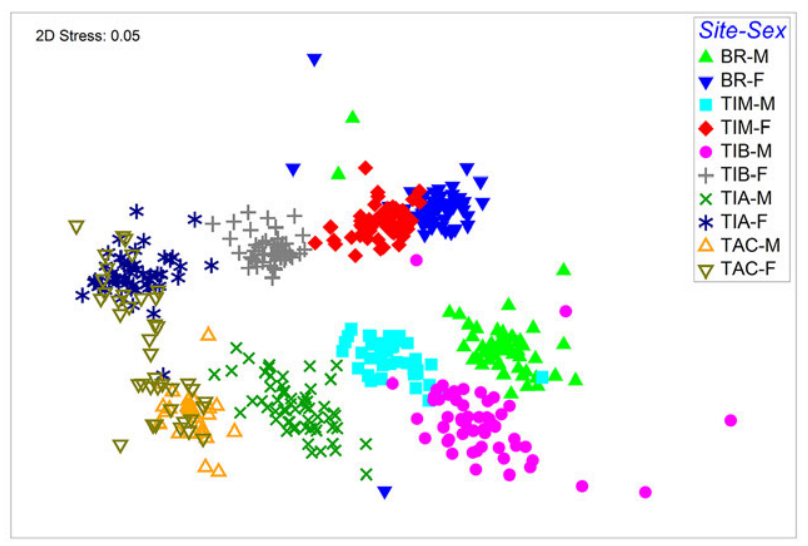

Fig. 3. - Non-metric multi-dimensional scaling (MDS) based on Euclidean distance, among defined groups by site-sex since standardized morphometric variables of Aratus pisonii. is sensitive to differences in multivariate dispersion between groups (Anderson et al. 2008). However, in the ordination of the samples by nMDS analyses, although there was an effect in the multivariate dispersion of the samples, there was also an effect of the sampling site. First, female crabs form a distinct group from male crabs, except in HD-TAC, where there was overlap between sexes. Second, both sexes tend to separate from each other depending on the sampling site. Females of arboreal mangroves (BR, TIM, TIB) are closer to each other and set apart from those of arbustive and dwarf mangroves, which do not differ among themselves. Males are arranged similarly to females (Fig. 3).

The CAP ordination in males was obtained from six main axes of coordinates $(m)$ and three for females, which explain $98.3 \%$ and $96.0 \%$ (respectively) of the total variation. Four parameters (CL, AL, RLCh, LLCh) were important for discriminating among female groups and allowed individuals to be correctly assigned in $88.37 \%$ of the cases $(228 / 258)$. In males, however only three variables (CL, AL and $\mathrm{HB}$ ) were important and allowed correct classification in $95.72 \%$ of the cases (246/247). Cross-validation of CAP shows that males of HD-TAC were correctly classified in $100 \%$ of the cases, followed by EA-BR $(98.04 \%)$ and MA-TIM (97.44\%), while for hypersaline mangroves of Tiraya Lagoon (HA-TIB and HAr-TIA) successes were above $90 \%$. Alternatively, females of HA-TIB were $100 \%$ correctly classified, followed by HArTIA and MA-TIM ( $>90 \%)$, while the greatest missclassification errors occurred in EA-BR and HD-TAC (Table 3). The strength of the association (canonical

Table 3. - Cross-validation results for canonical analysis of principal coordinates of the Aratus pisonii data.

\begin{tabular}{|c|c|c|c|c|c|c|c|}
\hline \multicolumn{8}{|c|}{ Males (for the choice of $m=6$ ) } \\
\hline Original group & $\mathrm{BR}$ & TIM & TIB & TIA & TAC & Total & $\%$ correct \\
\hline $\mathrm{BR}$ & 50 & 1 & 0 & 0 & 0 & 51 & 98.04 \\
\hline TIM & 1 & 38 & 0 & 0 & 0 & 39 & 97.44 \\
\hline TIB & 3 & 2 & 49 & 0 & 0 & 54 & 90.74 \\
\hline TIA & 0 & 3 & 0 & 55 & 1 & 59 & 93.22 \\
\hline TAC & 0 & 0 & 0 & 0 & 54 & 54 & 100.00 \\
\hline \multicolumn{8}{|c|}{ Females (for the choice of $m=3$ ) } \\
\hline Original group & $\mathrm{BR}$ & TIM & TIB & TIA & TAC & Total & $\%$ correct \\
\hline $\mathrm{BR}$ & 50 & 5 & 1 & 0 & 0 & 56 & 89.29 \\
\hline TIM & 4 & 52 & 1 & 0 & 0 & 57 & 91.23 \\
\hline TIB & 0 & 0 & 55 & 0 & 0 & 55 & 100.00 \\
\hline TIA & 0 & 0 & 1 & 47 & 2 & 50 & 94.00 \\
\hline TAC & 0 & 0 & 0 & 16 & 24 & 40 & 60.00 \\
\hline
\end{tabular}



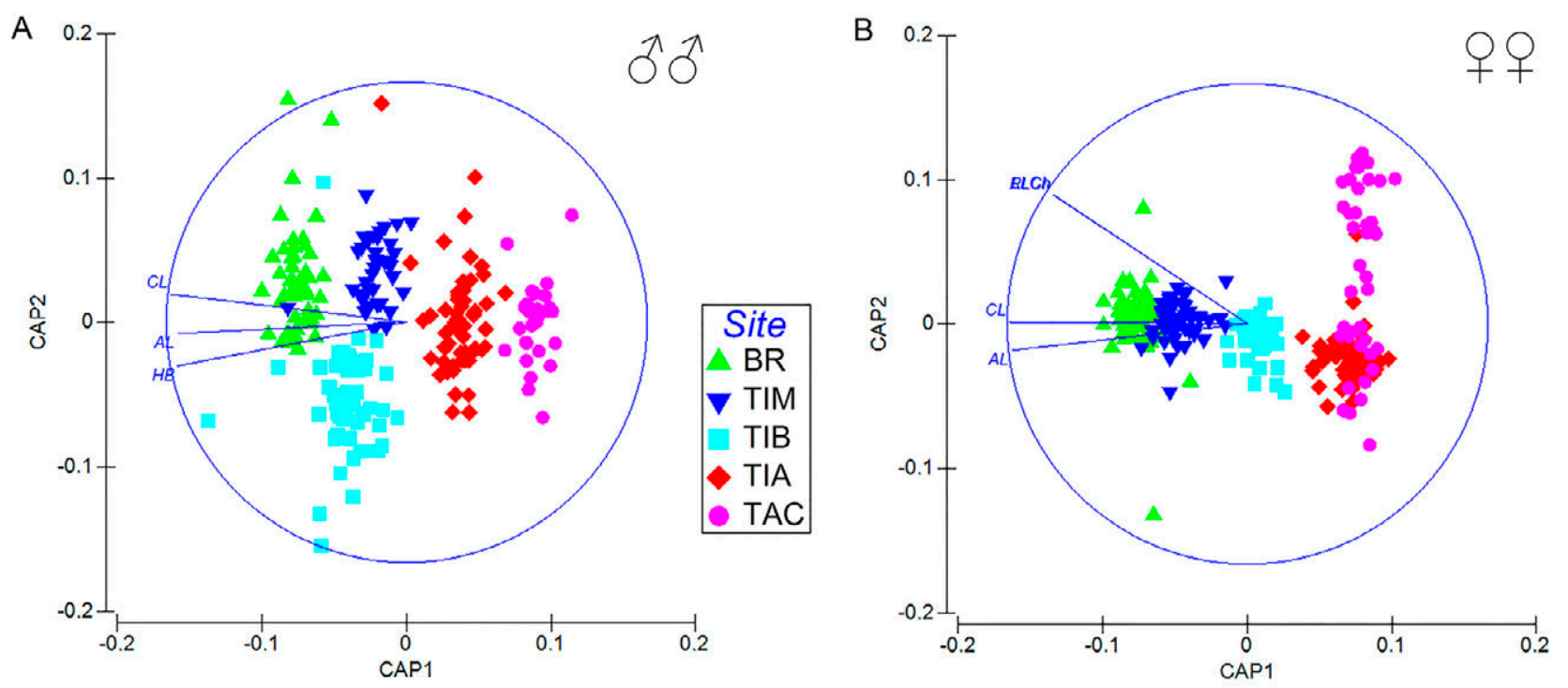

Fig. 4. - Multivariate ordination of samples on canonical analysis of principal coordinates of males (A) and females (B) of Aratus pisonii, based on Euclidean distance. Bi-plot indicates the morphometric variables (vectors) exerting the strongest influence on the patterns in multivariate space (only Pearson's correlation $r>0.95$ are shown).

Table 4. - Results of the SIMPER analysis showing the average squared Euclidean distance (SED) and contribution percentage of each morphometric variable of Aratus pisonii to dissimilarity between sites for each sex. The SED that have the highest dissimilarity ( $>50$ ) between each pair of sites are placed in bold.

\begin{tabular}{|c|c|c|c|c|c|c|c|c|c|c|}
\hline Sites & BR and TIM & $\mathrm{BR}$ and TIB & TIM and TIB & BR and TIA & TIM and TIA & TIB and TIA & $\mathrm{BR}$ and $\mathrm{AC}$ & TIM and TAC & IB and TAC & TIA and TAC \\
\hline \multicolumn{11}{|l|}{ Males } \\
\hline SED & 14.06 & 13.23 & 15.82 & 41.04 & 13.31 & 34.14 & 82.52 & 37.14 & 70.46 & 12.21 \\
\hline $\mathrm{CL}$ & 20.14 & 19.76 & 4.13 & 31.26 & 33.46 & 15.00 & 34.87 & 39.17 & 22.27 & 33.02 \\
\hline CW2 & 2.76 & 5.34 & 1.22 & 3.34 & 4.40 & 1.28 & 2.28 & 2.07 & 0.66 & 3.33 \\
\hline AW & 8.83 & 8.72 & 2.38 & 12.56 & 14.90 & 7.64 & 10.15 & 11.27 & 7.13 & 6.51 \\
\hline $\mathrm{AL}$ & 18.71 & 13.78 & 10.47 & 20.20 & 14.73 & 15.29 & 19.48 & 16.70 & 15.80 & 12.95 \\
\hline $\mathrm{HB}$ & 7.17 & 2.28 & 4.14 & 8.00 & 7.58 & 7.51 & 8.64 & 8.98 & 8.57 & 8.41 \\
\hline RLCh & 13.31 & 18.81 & 25.78 & 8.22 & 7.72 & 18.94 & 9.44 & 9.36 & 17.64 & 13.07 \\
\hline $\mathrm{LLCh}$ & 14.37 & 14.66 & 20.69 & 10.31 & 10.37 & 18.03 & 9.77 & 8.96 & 15.41 & 12.52 \\
\hline $\mathrm{RHCh}$ & 8.03 & 9.92 & 15.90 & 2.86 & 2.64 & 7.60 & 2.62 & 1.54 & 6.15 & 4.54 \\
\hline $\mathrm{LHCh}$ & 6.69 & 6.70 & 15.30 & 3.24 & 4.20 & 8.72 & 2.75 & 1.94 & 6.37 & 5.67 \\
\hline \multicolumn{11}{|l|}{ Females } \\
\hline SED & 5.96 & 25.83 & 12.76 & 77.67 & 53.47 & 17.46 & 86.01 & 61.45 & 24.96 & 11.02 \\
\hline CL & 21.10 & 34.43 & 31.13 & 33.89 & 31.86 & 28.60 & 33.78 & 31.24 & 24.29 & 3.88 \\
\hline CW2 & 3.44 & 3.76 & 5.32 & 2.96 & 3.34 & 2.88 & 3.38 & 3.76 & 2.96 & 2.46 \\
\hline AW & 21.01 & 13.89 & 14.48 & 13.36 & 14.42 & 13.82 & 20.16 & 22.92 & 26.03 & 17.20 \\
\hline $\mathrm{AL}$ & 20.63 & 18.12 & 14.70 & 18.60 & 16.35 & 18.34 & 22.59 & 20.52 & 22.22 & 8.86 \\
\hline $\mathrm{HB}$ & 4.54 & 6.40 & 9.47 & 7.57 & 9.27 & 9.05 & 7.56 & 9.00 & 7.72 & 4.59 \\
\hline RLCh & 10.81 & 8.33 & 10.31 & 8.14 & 9.40 & 9.15 & 4.70 & 4.98 & 4.93 & 16.68 \\
\hline $\mathrm{LLCh}$ & 11.38 & 9.24 & 9.46 & 9.85 & 10.38 & 11.62 & 5.00 & 4.70 & 5.18 & 20.34 \\
\hline $\mathrm{RHCh}$ & 3.51 & 2.96 & 2.55 & 3.05 & 2.72 & 3.75 & 1.47 & 1.45 & 3.25 & 13.28 \\
\hline $\mathrm{LHCh}$ & 3.57 & 2.87 & 2.59 & 2.58 & 2.27 & 2.78 & 1.37 & 1.43 & 3.42 & 12.70 \\
\hline
\end{tabular}

correlation) between the multivariate ordination with the hypothesis of differences among sampling sites of the first two canonical axes was 0.98 (CAP1) and 0.72 (CAP2) in the male ordination (Fig. 4A) and 0.98 (CAP1) and 0.54 (CAP2) in the female ordination (Fig. 4B). Finally, the trace statistic showed that the differences among centroids (of sampling sites) in the multivariate space were significant for males and females

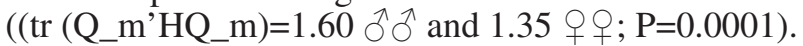

SIMPER results complement those obtained with the CAP (Table 4). The greatest dissimilarities $(>50)$ were found between crabs from arboreal mangroves (EA-BR, HA-TIB) and crabs from HD-TAC; male crab populations in the remaining mangroves showed lower values of dissimilarity $( \pm 40)$. In females the greatest distances $(>50)$ also appeared between the crabs inhabit- ing arboreal mangrove forest (EA-BR, MA-TIM) and crabs living in hypersaline mangroves with less structural development (HAr-TIA, HD-TAC). Female crab populations in the remaining mangroves showed lower values of dissimilarity $(<30)$. Morphometric variables that contributed to these dissimilarities were those related to carapace size (CL), abdomen size (AL, AW) and length of chelipeds (RLCh, LLCh) in both genders. Only in males did HB also contribute to these differences, although with a smaller impact than the other variables.

\section{DISCUSSION}

The present study tests the hypothesis that Aratus pisonii populations living in five mangrove forests with different environmental characteristics and structural 
development are separated according to differences in body morphology. The results of the multivariate analysis show males forming five clusters, suggesting five morphological groups in five evaluated populations; on the other hand, females comprise four groups in five examined populations and show a greater proximity between them. The findings support the existence of sexual dimorphism. The length of the carapace and abdomen in both sexes were the characters that most contributed to the discrimination between sites. Only in males, was HB a character that provided separation between sites, although with less importance. Cheliped morphology in females also contributed to the separation between sites: particularly females from HD-TAC showed a wide variability associated with the length and height of the chelipeds.

Male and female body size decreases as both, the mangrove structural development diminishes and soil salinity increases, in consonance with a greater contribution of the site factor for the variation components. However, the interaction between site and sex indicates an independent behaviour for males and females, which seems to be governed by the characteristics of each particular habitat. Separate analysis of the sexes revealed that there are significant differences in response to habitat conditions for each of them. Males and females did not differ in body size in three of the five mangroves; males reached a larger size at only two sites (both under hypersaline conditions), indicating sexual dimorphism in body size for these localities. This finding suggests a variable response of each sex to the particular habitat conditions, showing a wide plasticity in this morphometric measure. However, the sexual dimorphism of chelipeds remains constant at all sites. Coastal heterogeneous environments can have a significant influence on phenotypic expression in crustaceans (Overton 1999).

It has been observed in studies carried out on mangroves in Latin America (Venezuela and Brazil) that the sexual dimorphism in body size (CW1) varies by location; in some cases males reach greater size than females (Warner 1967, Conde and Díaz 1989a, b, Leme et al. 2014), while in others there is no difference in size between the sexes (Conde et al. 1989, 2000, Nicolau and Oshiro 2002). A differential growth rate could explain the observed differences in size, as was suggested by Warner (1967) in Jamaica, and Díaz and Conde (1989) in Venezuela, outlining that females probably invest a significant amount of energy for reproductive purposes in concordance with a longer intermoult time, which slows down their growth in comparison with males. On the other hand, greater availability of resources observed in mangroves with higher structural development (López and Conde 2013), combined with a more stable environment, a constant supply of fresh water in estuarine mangroves (López 2010) and stable salinity in marine mangroves should contribute to a constant investment of energy for growth and reproduction in both sexes, thereby diluting the sexual dimorphism in size at these localities. The behaviour of the hepatopancreas reserves in the study area supports the above hypothesis, remaining stable between seasons (wet vs dry) in estuarine and marine crabs, and suggesting a compensation of hepatopancreas reserves as a result of food consumed (López 2010); a situation evidenced in other marine decapod crustaceans (Kennish 1997, Rosa and Nunes 2003). In hypersaline mangroves with little structural development and a lower variety of resources (TIB, TIA, TAC), hepatopancreas reserves suffered a decline during the rainy months coinciding with the period of greatest reproductive activity (López 2010). In hypersaline mangroves there seems to exist a compromise between growing or reproducing: the energy invested for growth could be limited by its use in maintenance (osmoregulation, respiration and temperature control). A compromise in the allocation of energy directed to growth or reproduction has been observed in other mangrove sesarmids when they live in waters with high salinity (48-65), so that the energy gained through the consumption of food is directed towards excretion (osmoregulation) and breathing, negatively affecting the investment in growth or reproduction (Gillikin et al. 2004). Nevertheless, the absence of dimorphism in crabs from the hypersaline mangrove with less structural development (TAC) is paradoxical, although it can be interpreted as if both sexes are so severely affected by habitat conditions that they are equally affected with restrained investment in growth.

Females formed only four morphological groups from five studied populations, showing an overlap in mangrove habitats with less structural development and increased salinity (TIA and TAC). However, these groups of females showed differences in cheliped morphology, displaying greater strength (larger height and length) in the dwarf hypersaline mangrove (TAC). Decapod chelipeds are a good example of a multifunctional organ, whose main uses include taking food and having interactions with conspecifics for food or partners (in males) (Lee and Seed 1992). The significance of the observed differences in cheliped morphology in females could be related to food, particularly in the biomechanical properties of the leaves of mangroves in each habitat, which could affect the functionality of this appendix when handling more leathery or sclerophyllous leaves (Smith and Palmer 1994). Preliminary results found that the leaves of HSM-TAC are significantly more sclerophyllous than those from HArM-TIA, HAM-TIB and MAM-TIM (289.83 \pm 4.59 $\mathrm{g} \mathrm{m}^{-2}$ vs $185.71 \pm 2.53 \mathrm{~g} \mathrm{~m}^{-2}, 169.98 \pm 2.93 \mathrm{~g} \mathrm{~m}^{-2}, 178.39$ $\pm 4.11 \mathrm{~g} \mathrm{~m}^{-2}$ respectively; López et al. unpublished data); and have a higher $\mathrm{C}: \mathrm{N}$ ratio (López 2010). An effect of the dietary manipulation on the size and strength of the chelipeds has been found in the crab Cancer productus, showing that its morphology is related to differential use in handling prey with different consistency during the individual's growth, affecting the size and performance of the appendix (Smith and Palmer 1994). Females from HD-TAC appear to be subjected to higher nutritional requirements than males due to the high energy demand in egg production and the low quality of the food (leaves) found in this place (Conde et al. 1995). It has been documented that crustacean females invest a large proportion of their energy in reproductive activities (gametogenesis), unlike the 
males, in which the investment of energy in sperm production is relatively insignificant (Macintosh 1984, Kyomo 1988, 2000). In previous studies cannibalism involving the consumption of eggs of their fellows has been mentioned, especially in females from HD-TAC (López and Conde 2013). Moreover, the C:N relationship in hepatopancreas reserves was significantly lower, showing an inferior food quality in this locality (López 2010). The above findings support the idea that the female population is subjected to harsher environmental conditions.

The plasticity of the structures used for feeding should be favoured when a) the strength of the resource or prey in the diet varies on a space-time scale, b) the phenotypic response directly correlates to the success in obtaining food, and c) there is a low cost associated with plasticity in the fitness of the individual (Stearns 1989). In our study area we observed in previous studies a variation in the characteristics of the leaves (polyphenols, $\mathrm{C}: \mathrm{N}$ ) both spatially, in gradient structural development of mangroves (Conde et al. 1995, López 2010), and according to the season, drought or rain (Rondón and Conde unpublished data). Therefore, it is proposed that the presence of females with more robust chelae is related to an increase in the difficulty of manipulation (scraping, cutting) of stronger sclerophyllous leaves (>polyphenols and $\mathrm{C}: \mathrm{N}$ ), providing better tolerance to environmental conditions. This is interpreted as an important adaptive strategy to a changing or stressful environment, as has been observed in other marine crustaceans (Via et al. 1995, Trussell and Smith 2000). However, manipulation experiments under controlled conditions must be carried out to confirm this statement.

Morphological features are affected by both genetic and environmental factors (Murta 2000), so morphological variation may reflect genetic differences between populations and/or environmental differences between localities (Tzeng 2004). The differences found between populations of $A$. pisonii are not surprising, considering the plasticity that this species has shown in previous studies (Conde et al. 2000, Conde and Díaz 1989a, 1992, Negreiros-Fransozo 2002). Like other mangrove crustaceans, $A$. pisonii has a planktonic larval phase (Warner 1967, Díaz and Bevilacqua 1986, 1987). During larval dispersal at sea a high gene flow can be expected between different populations, hindering the isolation of subpopulations that would promote a change in their genetic makeup (Conde 1990) and supporting the hypothesis of a post-settlement response of larvae as a result of specific environmental conditions in each mangrove (phenotypic plasticity). Previous population transplantation experiments conducted in the mangroves under study support this hypothesis (Conde and Díaz 1989a). However, it is possible that in some locations (e.g. HD-TAC, which is situated near the Paraguaná Refining Centre) larval retention occurs due to potential barriers (industrial pollution, changing sea-current patterns) (Ramos et al. 2012), which could lead to local higher retention rates of larvae, promoting a long-term degree of reproductive isolation.

Our results suggest that the difference in crab morphology between sites is related to a particular combi- nation of environmental factors in each habitat, leading to the formation of morphological groups in five males and four females, in which the structural development of the mangrove (representing the availability of resources and salinity, which compromise the energy budget and affect the quality of mangrove leaves) play an important role. In addition, females respond differentially to males to these conditions: the presence of more robust chelipeds in females in the HD-TAC than in females in similar environmental conditions (e.g. HArM-TIA) seems to reflect an adaptation to the biomechanical properties of the leaves, in which the manipulation of those with a higher grade of sclerophylly could be affecting the functionality of this appendix.

\section{ACKNOWLEDGEMENTS}

This research was supported by the Instituto Venezolano de Investigaciones Científicas (IVIC), project No. 467. The authors are very grateful to Wilmer Rojas for his help with editing the graphics and to Néstor, Marina and Bernardo Viloria for their assistance in the field activities. Our gratitude extends to Gilberto González for his cooperation with processing of crabs in the laboratory. The authors also thank José V. Montoya, Oscar Andrés López and the anonymous reviewers for their comments.

\section{REFERENCES}

Anastasiadou C., Leonardos I.D. 2008. Morphological Variation among Populations of Atyaephyra desmarestii (Millet, 1831) (Decapoda: Caridea: Atyidae) from Freshwater Habitats of Northwestern Greece. J. Crustac. Biol. 28: 240-247. http://dx.doi.org/10.1163/20021975-99990370

Anderson M. 2001. A new method for non-parametric multivariate analysis of variance. Austral Ecol. 26: 32-46. http://dx.doi.org/10.1111/j.1442-9993.2001.01070.pp.x

Anderson M., Willis T. 2003. Canonical analysis of principal coordinates: A useful method of constrained ordination for ecology. Ecology 84: 511-525.

http://dx.doi.org/10.1890/0012-9658(2003)084[0511:CAOPC A]2.0.CO;2

Anderson M., Gorley R., Clarke K. 2008. PERMANOVA+for PRIMER: guide to software and statistical methods. PRIMERE, Plymouth, UK, 214 pp.

Bas C., Sardà F. 1998. Long-Term Morphometric Variations in a Population of the Deep-Sea Shrimp Aristeus antennatus (Risso, 1816) (Decapoda, Aristeidae). Crustac. Int. J. Crustac. Res. 71: 369-377. http://dx.doi.org/10.1163/156854098X00482

Cabral H., Marques J., Rego A., et al. 2003. Genetic and morphological variation of Synaptura lusitanica Capello, 1868, along the Portuguese coast. J. Sea Res. 50: 167-175. http://dx.doi.org/10.1016/S1385-1101(03)00060-

Charnov E. 1990. Relative Size At the Onset of Maturity (Rsom) Is an Interesting Number in Crustacean Growth (Decapoda, Pandalidae). Crustac. Int. J. Crustac. Res. 59: 108-109. http://dx.doi.org/10.1163/156854090X00381

Clarke K., Gorley R. 2006. Primer v6: User Manual/Tutorial. PRIMER-E, Plymouth, UK, 193 pp.

Conde J. 1990. Ecología poblacional del cangrejo de mangle Aratus pisonii (H. Milne-Edwards) (Brachyura: Grapsidae) en hábitats extremos. $\mathrm{PhD}$ thesis, Instituto Venezolano de Investigaciones Científicas, Caracas, 212 pp.

Conde J., Díaz H. 1989a. Productividad del habitat e historias de vida del cangrejo de mangle Aratus pisonii (H. Milne Edwards) (Brachyura, Grapsidae). Bol. Inst. Oceanogr. Venezuela 28: 113-120.

Conde J., Díaz H. 1989b. The mangrove tree crab Aratus pisonii in a tropical estuarine coastal lagoon. Est. Coast. Shelf Sci. 28: 
$639-650$. http://dx.doi.org/10.1016/0272-7714(89)90051-6

Conde J., Díaz H. 1992. Variations in intraspecific relative size, at the onset of maturity (RSOM) in Aratus pisonii (H. Milne, Edwards, 1837) (Decapoda, Brachyura, Grapsidae). Crustac. Int. J. Crustac. Res. 62: 214-216.

Conde J., Díaz H., Rodríguez G. 1989. Crecimiento reducido en el cangrejo de mangle Aratus pisonii (H. Milne-Edwards) (Brachyura: Grapsidae). Acta Cient. Venez. 40: 159-160.

Conde J., Flores S., Díaz H. 1995. Nitrogen and tannins in mangrove leaves might explain interpopulation variations in the crab Aratus pisonii. Acta Cient. Venez. 46: 303-304.

Conde J., Tognella M., Paes E., et al. 2000. Population and life history features of the crab Aratus pisonii (Decapoda: Grapsidae) in a subtropical estuary. Interciencia 25: 151-158.

Contreras H., Duarte C., Jaramillo E., et al. 2013. Morphometric variability in sandy beach crustaceans of Isla Grande de Chiloé, Southern Chile. Rev. Biol. Mar. Oceanogr. 48: 487-496. http://dx.doi.org/10.4067/S0718-19572013000300007

Deli T., Said K., Chatti N. 2014. Morphological differentiation among geographically close populations of the green crab Carcinus aestuarii Nardo, 1847 (Brachyura, Carcinidae) from the Tunisian coast. Crustac. Int. J. Crustac. 87: 257-283. http://dx.doi.org/10.1163/15685403-00003291

Díaz H., Bevilacqua M. 1986. Larval development of Aratus pisonii (Milne Edwards) (Brachyura, Grapsidae) from marine and estuarine environments reared under different salinity conditions. J. Coast. Res. 2: 43-49.

Díaz H., Bevilacqua M. 1987. Early Developmental Sequences of Aratus pisonii (H. Milne Edwards) (Brachyura, Grapsidae) under Laboratory Conditions. J. Coast. Res. 3: 63-70.

Díaz H., Conde J. 1988. On the food sources for the mangrove tree crab Aratus pisonii (Brachyura: Grapsidae). Biotropica 20: 348-350 http://dx.doi.org/10.2307/2388331

Díaz H., Conde J. 1989. Population dynamics and life history of the mangrove crab Aratus pisonii (Brachyura, Grapsidae) in a marine environment. Bull. Mar. Sci. 45: 148-163.

Erickson A., Saltis M., Bell S., et al. 2003. Herbivore feeding preferences as measured by leaf damage and stomatal ingestion: a mangrove crab example. J. Exp. Mar. Biol. Ecol. 289: 123-138. http://dx.doi.org/10.1016/S0022-0981(03)00039-X

Feller I., Chamberlain A. 2007. Herbivore responses to nutrient enrichment and landscape heterogeneity in a mangrove ecosystem. Oecologia 153: 607-616. http://dx.doi.org/10.1007/s00442-007-0760-9

Fernandez-Vergaz V., Lopez Abellan L., Balguerias E. 2000. Morphometric, functional and sexual maturity of the deep-sea red crab Chaceon affinis inhabiting Canary Island waters: Chronology of maturation. Mar. Ecol. Prog. Ser. 204: 169-178. http://dx.doi.org/10.3354/meps204169

García-Dávila C., Magalhães C., Guerrero J. 2005. Morphometric variability in populations of Palaemonetes spp. (Crustacea, Decapoda, Palaemonidae) from the Peruvian and Brazilian Amazon Basin. Iheringia, Sér. Zool. 95: 327-334. http://dx doi.org/10.1590/S0073-47212005000300013

Gillikin D., De Wachter B., Tack J. 2004. Physiological responses of two ecologically important Kenyan mangrove crabs exposed to altered salinity regimes. J. Exp. Mar. Biol. Ecol. 301: 93-109. http://dx doi.org/10.1016/j jembe 2003.09.024

Grandjean F., Bramard M., Avila-Zarza C., et al. 1997. Morphometry, Sexual Dimorphism and Size At Maturity of the White-Clawed Crayfish Austropotamobius pallipes pallipes (Lereboullet) From a Wild French Population At Deux-Sèvres (Decapoda, Astacidea). Crustac. Int. J. Crustac. 70: 31-44. http://dx.doi.org/10.1163/156854097X00320

Guill J., Hood C., Heins D. 2003. Body shape variation within and among three species of darters (Perciformes: Percidae). Ecol. Freshw. Fish 12: 134-140. http://dx.doi.org/10.1034/j.1600-0633.2003.00008.x

Hartnoll R. 1965. Notes on the marine grapsid crabs of Jamaica. Proc. Linn. Soc. Lond. 176: 113-147. http://dx.doi.org/10.1111/j.1095-8312.1965.tb00940x

Kennish R. 1997. Seasonal patterns of food availability: Influences on the reproductive output and body condition of the herbivorous crab Grapsus albolineatus. Oecologia 109: 209-218. http://dx.doi.org/10.1007/s004420050075

Kyomo J. 1988. Analysis of the relationship between gonads and hepatopancreas in males and females of the crab Sesarma intermedia, with reference to resource use and reproduction. Mar.
Biol. 97: 87-93.

http://dx.doi.org/10.1007/BF00391248

Kyomo J. 2000. Intraspecific variation of reproductive strategies of the crab Sesarma intermedia: a consequence of habitat variations. Bull. Mar. Sci. 66: 157-171.

Lee S., Seed R. 1992. Ecological implications of cheliped size in crabs: Some data from Carcinus maenas and Liocarcinus holsatus. Mar. Ecol. Prog. Ser. 84: 151-160. http://dx.doi.org/10.3354/meps084151

Leme M., Soares V., Pinheiro M. 2014. Population dynamics of the mangrove tree crab Aratus pisonii (Brachyura: Sesarmidae) in the estuarine complex of Cananéia-Iguape, São Paulo, Brazil. Pan-Am. J. Aquat. Sci. 9: 259-266.

López B. 2010. Ecología trófica y energética del cangrejo de mangle Aratus pisonii (Crustacea: Brachyura: Grapsidae) (H. MilneEdwards). PhD thesis, Instituto Venezolano de Investigaciones Científicas, Caracas, $242 \mathrm{pp}$.

López B., Conde J. 2013. Dietary variation in the crab Aratus pisonii (H. Milne Edwards, 1837) (Decapoda, Sesarmidae) in a mangrove gradient in northwestern Venezuela. Crustac. Int. J. Crustac. 86: 1051-1069. http://dx.doi.org/10.1163/15685403-00003220

López B., Barreto M., Conde J. 2011. Caracterización de los manglares de zonas semiáridas en el noroccidente de Venezuela. Interciencia 36: 888-893.

López-Sánchez B., Quintero-Torres E. 2015. Inversión reproductiva de Aratus pisonii (Decapoda: Sesarmidae): diferencias entre hábitats y análisis de rutas. Rev. Biol. Trop. 63: 385-399. http://dx.doi.org/10.15517/rbt.v63i2.15178

Macintosh D. 1984. Ecology and productivity of Malaysian mangrove crab population. In: Soepadmo E., Rao A.N., Macintosh D.J. (eds), Mangrove Environment: Research and Development. University of Malaya and Unesco, pp. 354-377.

Maynou F., Sardà F. 1997. Nephrops norvegicus population and morphometrical characteristics in relation to substrate heterogeneity. Fish. Res. 30: 139-149. http://dx.doi.org/10.1016/S0165-7836(96)00549-8

MINAMB. 2004. Sistema Nacional de Información Hidrológica y Metereológica. DGSICASV. División de Hidrología y Metereología. Ministerio del Poder Popular para el Ambiente. Caracas, República Bolivariana de Venezuela. (In digital format).

Muiño R., Fernández L., González-Gurriarán E., et al. 1999. Size at maturity of Liocarcinus depurator (Brachyura: Portunidae): a reproductive and morphometric study. J. Mar. Biol. Ass. UK 79: 295-303. http://dx.doi.org/10.1017/S0025315498000320

Murta A. 2000. Morphological variation of horse mackerel (Trachurus trachurus) in the Iberian and North African Atlantic: implications for stock identification. ICES J. Mar. Sci. 57: 1240-1248. http://dx.doi.org/10.1006/jmsc.2000.0810

Negreiros-Fransozo M. 2002. Size Variation in the Grapsid Crab Aratus pisonii (H. Milne-Edwards, 1837) Among Populations of Different Subtropical Mangroves. In: Escobar-Briones E., Alvarez F. (eds), Modern Approaches to the Study of Crustacea. Springer US, pp. 183-188. http://dx.doi.org/10.1007/978-1-4615-0761-1 29

Nicolau C., Oshiro L. 2002. Aspectos reprodutivos do caranguejo Aratus pisonii (H. Milne Edwards) (Crustacea, Decapoda, Grapsidae) do manguezal de Itacuruçá, Rio de Janeiro, Brasil. Rev. Bras. Zool. 19: 167-173. http://dx.doi.org/10.1590/S0101-81752002000600016

Overton J. 1999. Morphometrics and Ecology of the mud crab (Scylla spp.) from Southeast Asia. In: Keenan C.P., Blackshaw A. (eds), Mud Crab Aquaculture and Biology. ACIAR Proceedings No.78. Australian Centre for International Agricultural Research, Canberra, pp. 35-42.

Ramos R., Bastidas C., García E. 2012. Ensayos de toxicidad con sedimentos marinos del occidente de Venezuela. Cienc. Mar. 38: 119-127. http://dx.doi.org/10.7773/cm.v38i1A.1939

Rosa R., Nunes M. 2003. Biochemical composition of deep-sea decapod crustaceans with two different benthic life strategies off the Portuguese south coast. Deep-Sea Res. Part I 50: 119-130. http://dx.doi.org/10.1016/S0967-0637(02)00147-4

Sampedro M., González-Gurriarán E., Freire J., et al. 1999. Morphometry and Sexual Maturity in the Spider Crab Maja squinado (Decapoda: Majidae) in Galicia, Spain. J. Crustac. Biol. 19: 578-592. http://dx.doi.org/10.2307/1549263 
358 • B. López-Sánchez et al.

Smith L., Palmer A. 1994. Effects of manipulated diet on size and performance of brachyuran crab claws. Science 264: 710-712. http://dx.doi.org/10.1126/science.264.5159.710

Stearns S. 1989. The Evolutionary Significance of Phenotypic Plasticity. Bioscience 39: 436-445. http://dx.doi.org/10.2307/1311135

Trussell G., Smith L. 2000. Induced defenses in response to an invading crab predator: an explanation of historical and geographic phenotypic change. Proc. Natl. Acad. Sci. U.S.A. 97: 2123-2127.

http://dx.doi.org/10.1073/pnas.040423397
Tzeng T-D. 2004. Stock identification of sword prawn Parapenaeopsis hardwickii in the East China Sea and Taiwan Strait inferred by morphometric variation. Fish. Sci. 70: 758-764. http://dx.doi.org/10.1111/j.1444-2906.2004.00868.x

Via S., Gomulkiewicz R., De Jong G., et al. 1995. Adaptive phenotypic plasticity: consensus and controversy. Trends Ecol. Evol. 10: 212-217. http://dx.doi.org/10.1016/S0169-5347(00)89061-8

Warner G. 1967. The life history of the mangrove tree crab, Aratus pisonii. J. Zool. 153: 321-335.

http://dx.doi.org/10.1111/j.1469-7998.1967.tb04066.x 